\title{
Studentvikar i allmennpraksis - hvilke regler gjelder?
}

\author{
Sommeren er høysesong for medisinstudenter til å skaffe seg praktisk erfaring fra allmennlegepraksiser. \\ Det er noen juridiske problemstillinger som bør avklares før arbeidet starter.
}

Legeforeningens juridiske avdeling får flere henvendelser hvert år med spørsmål om hvilke arbeidsoppgaver medisinstudenter og leger med turnuslisens kan utføre på et allmennlegekontor. Problemstillingen er aktuell i sommersesongen når mange kandidater mellom studiesemesterne eller i påvente av turnustjeneste henter erfaring fra legekontorer.

Medisinstudenter kan i henhold til forskrift om lisens til helsepersonell $\S \S 1$ og 2 få lisens etter at eksamen i niende semester er avlagt, eventuelt dersom de har mindre enn ett år igjen av studiet (1). Lisens kan også gis til leger som har gjennomført studiet og venter på turnusplass (gjerne omtalt som turnuslisens). I noen EØS-land, herunder Norge, gis autorisasjon når studiet er gjennomført. Disse legene må som hovedregel gjennomføre turnustjeneste før de kan få refusjonsrett $\mathrm{i}$ allmennlegepraksis (2) og likestilles i denne artikkelen derfor med legestudenter som får lisens. Studenter med autorisasjon etter endt studium fra et annet EØS-land enn Norge kan omfattes av særregler. Disse blir ikke omtalt nærmere.

For oversiktens skyld blir leger med lisens/manglende turnustjeneste i denne artikkelen omtalt som «studenten».

\section{Arbeid med lisens/ manglende turnustjeneste}

I henhold til forskrift om lisens til helsepersonell $\S 4$ er utgangspunktet at en lege med lisens ikke kan jobbe som vikar for en allmennlege, da lisensen ikke gir adgang til å utøve legevirksomhet av selvstendig karakter (1). Det er heller ikke adgang til å sende regning til Helfo i eget navn for legevirksomheten.

Imidlertid kan studenten ifølge samme paragraf utføre arbeid i allmennlegepraksis såfremt vedkommende er assistent hos praktiserende lege (1). Dette kan organiseres slik at f.eks. kollegaen til en fraværende fastlege (heretter omtalt som «ansvarlig lege») har ansvaret for fastlegens pasientliste under fraværet. Studenten kan da arbeide som assistent, på fraværende leges pasientliste, men under personlig veiledning fra ansvarlig lege. Det er ikke krav om at ansvarlig lege må være til stede under konsultasjonen til enhver tid, men vedkommende må være i nærheten for drøftelser og veiledning.
I praksis innebærer det at den ansvarlige legen og studenten kan foreta sine konsultasjoner samtidig. Hensynet til forsvarlig veiledning vil vanligvis være oppfylt dersom legene arbeider på det samme legekontoret.

I og med at ansvarlig lege utad er ansvarlig for det arbeidet studenten utfører, er det viktig at det på forhånd og underveis vurderes hvilke arbeidsoppgaver studenten kan utføre. Det sentrale vurderingstemaet er at arbeidet gjennomføres forsvarlig (3). Forsvarligheten omfatter bl.a. «krav til faglig forsvarlighet og omsorgsfull hjelp som kan forventes ut fra helsepersonellets kvalifika-

\section{«Studenter med studentlisens har ikke full forskrivningsrett»}

sjoner, arbeidets karakter og situasjonen for øvrig». I tillegg skal legen «innrette seg etter sine faglige kvalifikasjoner, og skal innhente bistand eller henvise pasienter videre der dette er nødvendig og mulig». Forsvarlighetskravet retter seg til legen som gjennomfører behandlingen og til ansvarlig lege som har delegert arbeidet.

\section{Refusjoner}

I utgangspunktet må legen ha refusjonsrett på selvstendig grunnlag eller ha inngått en veilederavtale med kommunen for å kreve refusjonene dekket. Disse kravene oppfyller ikke studenten og har derfor ikke rett til selv å fremme krav om refusjon. Studenten kan imidlertid utføre arbeid som utløser rett til refusjon etter normaltariffen så lenge dette skjer innenfor de krav som stilles til forsvarlig veiledning. Det foreligger en relativt etablert praksis for at den ansvarlige lege, hvis han har avtale om direkteoppgjør med folketrygden, kan fremme krav om refusjon for behandling utført av studenten. Legen vil da være ansvarlig for det krav som fremmes overfor Helfo, herunder ansvarlig for det medisinske arbeid utført av studenten.

Dersom refusjonene skal bli innsendt via den ansvarlige legen, anbefaler vi at man i forkant kontakter Helfo og informerer om perioden som studenten skal arbeide på legekontoret. For ordens skyld gjør vi oppmerksom på at Helfo erfaringsvis har noe ulik praksis i sin håndtering av disse sakene. Enkelte medisinstudenter og medisinske kandidater har opplevd problemer med å utløse rett til refusjon fra folketrygden gjennom slikt arbeid. Helfo bør derfor anmodes om å gi en skriftlig aksept for aktuell organisering før arbeidet begynnes. Vi anbefaler også at det inngås en skriftlig avtale mellom den ansvarlige legen og studenten om hvordan inntektene som følge av refusjonskravene skal fordeles.

\section{Resepter og sykmeldinger}

I henhold til forskrift om lisens til helsepersonell $\S 4$ gis studenten rett til å forskrive legemidler $\mathrm{i}$ gruppe $\mathrm{B}$ og $\mathrm{C}$ i forbindelse med arbeidet (1). Studenten kan derimot ikke skrive ut på blåresept. I merknaden til $\S 8$ fremkommer det at «kun leger med full forskrivningsrett kan forskrive medisiner på blåresept». Studenter med studentlisens har ikke full forskrivningsrett. Når studenten ikke har adgang til å utøve legevirksomhet av selvstendig karakter, er vår forståelse at dette innebærer at vedkommende heller ikke kan utstede sykmeldinger.

Praktisk erfaring fra allmennlegekontor er verdifullt for medisinstudenter og medisinske kandidater. Samtidig er erfaring som veileder for disse legene lærerikt. Dersom det oppstår juridiske spørsmål underveis, kan Legeforeningens jurister kontaktes.

\section{Christine Palm}

Avdeling for jus og arbeidsliv Legeforeningen

\section{Litteratur}

1. FOR-2000-12-21-1379. Forskrift om lisens til helsepersonell. https://lovdata.no/dokument/SF/ forskrift/2000-12-21-1379 (30.5.2016).

2. FOR-2005-12-19-1653. Forskrift om veiledet tjeneste for å få adgang til å praktisere som allmennlege med rett til trygderefusjon. $\S 3$ (b). https://lovdata.no/dokument/SF/forskrift/ 2005-12-19-1653 (30.5.2016).

3. LOV-1999-07-02-64. Lov om helsepersonell m.v. (helsepersonelloven). https://lovdata.no/ dokument/NL/lov/1999-07-02-64\#KAPITTEL_4 (30.5.2016) 